\title{
The Recent temperate foraminiferal biofacies of the Gippsland Shelf: an analogue for Neogene environmental analyses in southeastern Australia
}

\author{
ANDREW J. SMITH ${ }^{1}$, STEPHEN J. GALLAGHER ${ }^{1}$, MALCOLM WALLACE ${ }^{1}$, GUY HOLDGATE ${ }^{1}$, JIM DANIELS $^{1} \&$ \\ JOCK KEENE ${ }^{2}$ \\ ${ }^{1}$ School of Earth Sciences, The University of Melbourne, Victoria 3010, Australia (e-mail: sjgall@unimelb.edu.au) \\ ${ }^{2}$ School of Geosciences, The University of Sydney, New South Wales 2006, Australia
}

\begin{abstract}
This study describes the foraminiferal biofacies of a temperate stenohaline shelf and associated euryhaline marine lakes of Gippsland in southeast Australia. The study incorporates facies analyses and interpretations of three types of foraminiferal distributional data: forms alive at the time of collection, recently dead forms and relict forms. Four principal biofacies types occur: (1) the euryhaline marine Gippsland Lakes silts and sands; (2) inner shelf medium to coarse quartz-rich sands and bioclastic silty sands; (3) medium shelf bryozoan-rich bioclastic silt and silty sand; (4) outer shelf bryozoan- and plankton-rich silts and fine sands.

The euryhaline marine Gippsland Lakes silts and sands contain abundant Ammonia beccarii and Eggerella, with minor Quinqueloculina, Elphidium and Discorbinella. The Gippsland inner shelf biofacies (0-50 m depths) consists of medium to coarse quartz-rich sands and bioclastic silty sand. Abundant living, relict and recently dead miliolids occur in the inner shelf with rare planktonic forms. Common planktonic foraminifera, with Cibicides, Parrellina, Elphidium and Lenticulina and relict forms occur in the bryozoan-rich bioclastic silt and silty sand of the Gippsland middle shelf (50-100 m depth). Bryozoan and plankton-rich silts and fine sand occur in the outer shelf to upper slope facies (100-300 m) below swell wave base on the Gippsland Shelf. A diverse fauna with common textulariids, Uvigerina, Bulimina, Anomalinoides and Astrononion and rare relict forms, occurs in this biofacies. Planktonic foraminifera and Uvigerina are most abundant at the shelf break due to local upwelling at the head of the Bass Canyon.

Estimates of faunal production rates from live/dead ratios and full assemblage data suggest that the fauna of the Gippsland Shelf has not been significantly reworked by wave and/or bioturbation processes. Most relict foraminifera occur in the inner shelf, with minor relict forms in the middle to outer shelf. This pattern is similar to other shelf regions in Australia, where shelf areas were exposed during Pleistocene lowstand times, principally reworking pre-existing inner to middle shelf faunas. Correspondence analyses of the foraminiferal data yield a clear depth-related distribution of the faunal assemblage data. Most of the modern Gippsland Shelf fauna are cosmopolitan species and nearly a third are (semi-)endemic taxa suitable for regional palaeo-environmental studies. From biostratigraphic studies it is clear that the modern Gippsland foraminiferal assemblage evolved since Early Miocene times, with most elements present by the Late Miocene. Hence, the Recent Gippsland Shelf foraminiferal biofacies distribution is a good analogue for Neogene palaeo-environmental studies in the region. The longer ranging pre-Miocene mixture of epifaunal and infaunal taxa are deeper shelf cosmopolitan forms and are inferred to be more conservative since they evolved in relatively lower stress environments, typifying mesotrophic to eutrophic conditions compared to inner shelf epifaunal forms with ecological niches markedly affected by sea-level and temperature fluctuations in zones of constant wave action, in oligotrophic environments.

The foraminiferal and facies analogues of this study on the Gippsland Shelf can be used for palaeo-environmental analyses of the Gippsland and Otway Neogene sedimentary successions. Such improvements will lead ultimately to a better understanding of the evolution of the neritic realm in southeastern Australia, an area facing the evolving Southern Ocean during the Cenozoic. J. Micropalaeontol. 20(2): 127-142, December 2001.
\end{abstract}

\section{INTRODUCTION}

The Gippsland Shelf is the most southeasterly shelf region along the continental margin of Australia. Similar to other shelf areas in southern Australia, it is typified by cool-water or temperate carbonate deposition (James, 1997). Unlike the Lacepede and Otway margins along the southern coast of Australia, which are exposed to the full force of the Southern Ocean swells (James et al., 1992, 1994; Boreen et al., 1993), the Gippsland Shelf is relatively sheltered due to its easterly position with respect to the Bass Strait and Tasmania (Fig. 1). In addition, the Gippsland Shelf, unlike the other shelves listed above, has an arcuate morphology due the erosional effects of one of the largest submarine canyons, the Bass Canyon (Fig. 2 and Connolly, 1968) along Australia's southern margin.

While summaries of modern marine sediment distribution have been completed in the region by Jones \& Davies (1983), there have been no previous detailed studies on the foraminiferal distribution of the Gippsland Shelf. The modern foraminiferal distribution is better known in other parts of Australia and New Zealand. Hayward et al. (1999) summarized the distribution, biogeography and palaeo-environmental significance of Recent New Zealand shallow water benthic foraminifera. Various foraminiferal studies have been completed on the temperate shelf to marginal marine regions of Australia, for example: 


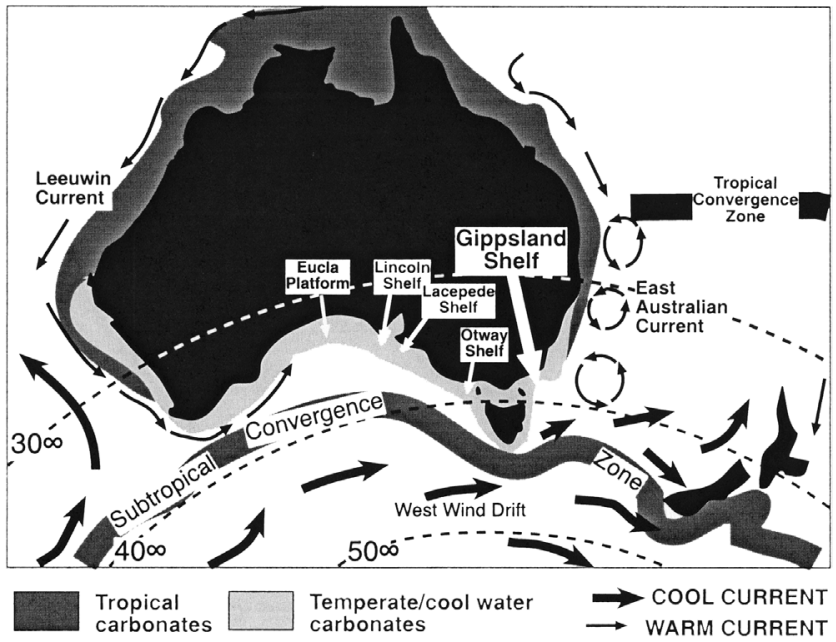

Fig. 1. The oceanographic setting of the Gippsland area and shelfal areas of southern Australia, adapted from Martinez (1994), James et al. (1999) and Li et al. (2000).

Broken Bay (Johnson \& Albani, 1978) and Port Hacking (Albani, 1968) in New South Wales; the Gippsland Lakes (Apthorpe, 1980), Western Port Bay (Bartels, 1979), Port Phillip Bay (Collins, 1973), Barwon Heads (Parr, 1945), Swan Bay (Cochrane, 1975) and Port Fairy (Collins, 1953) in Victoria; the Lincoln Shelf (Li et al., 1996a), Gulf of St Vincent (Cann et al., 1988, 1993), Port Gawler (Cann \& Gostin, 1985), the Lacepede Shelf (Li et al., 1996b) and the Yorke Peninsula (Cann et al., 1988) in South Australia and the southern margin of Western Australia by Li et al. (1999).

Thus, while the foraminiferal faunas of the southern and eastern margins of Australia are well known, there is a significant gap in knowledge about foraminiferal distribution in the southeastern region. Furthermore, none of the Australian studies listed above included any data on live foraminiferal assemblages or their relationship with sedimentary facies. This study describes, for the first time, the distribution of foraminifera of the Gippsland Shelf and associated marine lakes and includes facies analyses and interpretations of live/dead foraminiferal assemblages.

The distributions of modern foraminifera described in the previous studies listed above have been used as analogues for palaeo-environmental interpretations of the neritic, Cenozoic, cool-water carbonate successions of the Otway Basin (Gallagher et al. 1999; Gallagher \& Holdgate, 2000) and the Gippsland Basin (Gallagher \& Holdgate, 1996; Holdgate \& Gallagher, 1997; Gallagher et al., 2001) in Victoria. These thick sequences are, in part, laterally equivalent to economically important brown coal reserves and are the principal seal for hydrocarbon reserves in the region. The foraminiferal and facies analogues of this present study on the Gippsland Shelf will greatly improve palaeo-environmental analyses of Gippsland and Otway Tertiary sedimentary successions. Improvements in palaeoenvironmental analyses will lead ultimately to an better understanding of the evolution of the neritic realm in southeastern Australia, an area facing the evolving Southern Ocean during the Tertiary.

\section{METHODS}

The shelf samples in this study were collected from two transects across the Gippsland Shelf from 18 September to 5 October 1998 on the R/VFranklin. The samples were obtained using a Smith/McIntyre Grab, which yields approximately $0.1 \mathrm{~m}^{3}$ of undisturbed seabed sample.

Upon collection, the samples were preserved in an ethanol/ Rose Bengal solution. The Rose Bengal stains the protoplasm of living foraminifera, providing valuable information about the live/dead ratios within different assemblages (Murray, 1991). Subsequently, these samples were washed in a water/Rose Bengal solution following the technique outlined in Walton (1952). Foraminifers interpreted to have been alive at the time of collection showed consistent staining of the protoplasm within their final chamber/s. Foraminifera were interpreted to be relict or fossil forms if they showed evidence of alteration due to diagenesis or weathering. Most relict forms were found to have been ferruginized, with a limonite staining.

Twenty-two shelf samples were studied from the two transects across the Gippsland Shelf (Fig. 2). Transect A ranges in depth from 19 to $276 \mathrm{~m}$ for a distance of $120 \mathrm{~km}$. Transect $\mathrm{B}$ ranges in depth from 24 to $263 \mathrm{~m}$ over a distance of $90 \mathrm{~km}$.

The six Gippsland Lakes samples analysed in this study were collected by Apthorpe (1980) from the estuarine Gippsland Lakes (Fig. 2), including: Lake Wellington, Lake Victoria, Lake King, the Reeves Channel and from Lakes Entrance. The depth range for these samples is 2 to $11 \mathrm{~m}$ (Fig. 2). These samples were not preserved at time of collection and no information concerning live/dead ratios could be obtained.

Once samples were dried, around 300 foraminifera were picked from each of the 28 samples. Thirteen species of planktonic foraminifera and 129 species of benthonic foraminifera were identified amongst the 8000 foraminifera collected. Three types of distributional data were collected for the foraminiferal assemblage in each sample: forms interpreted to have been alive at time of collection (= live forms); forms with no evident protoplasm at time of collection nor any visible diagenetic alteration (= recently dead forms) and relict forms (see above).

Percentages of $\mathrm{CaCO}_{3}$ were calculated for each sample by dissolving approximately $0.3 \mathrm{~g}$ of the crushed sample using $50 \%$ $\mathrm{HCl}$ and measuring the amount of $\mathrm{CO}_{2}$ gas released (Carver, 1971). Facies analysis was completed by analyses of the dried unprocessed sample which was split and then viewed under a reflected light microscope.

Sea surface temperatures in the Gippsland Shelf along the transects ranged from $12.5^{\circ} \mathrm{C}$ to $15.5^{\circ} \mathrm{C}$ at time of collection (September-October 1998), increasing seawards, with temperature contours roughly following the bathymetric contours. Surface salinities varied little across the shelf at this time from $35.2 \%$ in the inner shelf to $35.1 \%$ in the mid-shelf to $35.3 \%$ in the outer shelf (Fig. 3).

\section{REGIONAL OCEANOGRAPHIC AND SEDIMENTOLOGICAL SETTING}

The Gippsland Shelf is a large $\left(32000 \mathrm{~km}^{2}\right)$ tapering shelf area occurring between $38^{\circ}$ and $41^{\circ} \mathrm{S}$ off the coast of southeast Australia, inland from a large submarine canyon that reaches a maximum depth of $4000 \mathrm{~m}$ (the Bass Canyon, Fig. 2). The 
Foraminiferal biofacies of the Gippsland Shelf, southeastern Australia

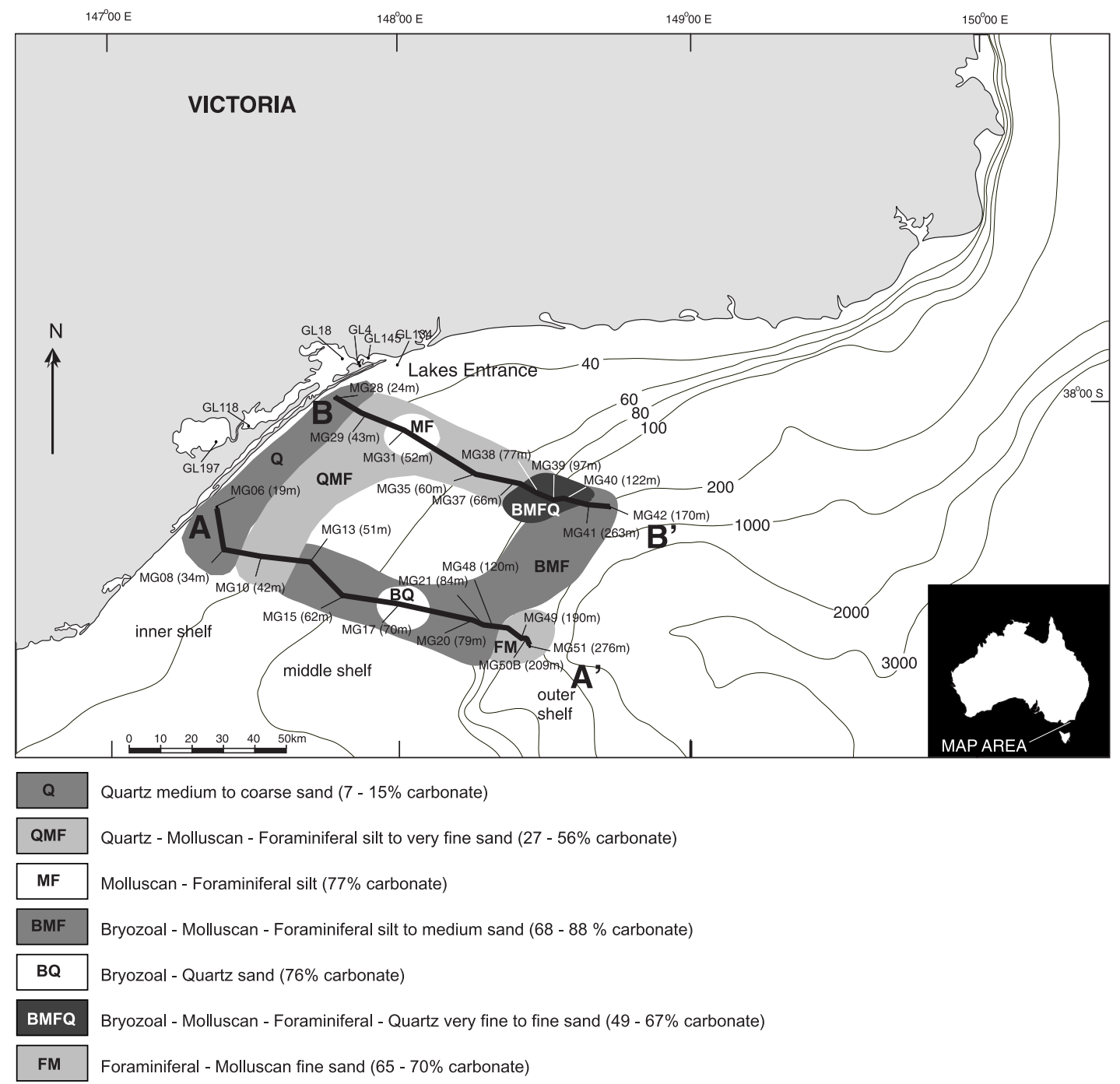

Note : Dominant clast type listed first

Fig. 2. Location and lithologies of the Gippsland Shelf and Lakes samples and transects (A-A' and B-B').

gradient across the Gippsland Shelf ranges from $0.06^{\circ}$ in the inner to middle shelf $(0-100 \mathrm{~m})$ to $1^{\circ}$ in the outer shelf $(100$ $200 \mathrm{~m})$. Slopes up to $6^{\circ}$ occur at the shelf break at the head of the Bass Canyon (deeper than 200 m, Fig. 3).

Mean sea surface temperatures for the Gippsland region vary from $16^{\circ} \mathrm{C}$ to $14^{\circ} \mathrm{C}$ in winter and $18^{\circ} \mathrm{C}$ to $20^{\circ} \mathrm{C}$ in summer (Levitus, 1982). Thus, it is a temperate or cool-water shelf (sensu James, 1997). The $15^{\circ} \mathrm{C}$ thermocline is at around $100 \mathrm{~m}$ in summer and the $10^{\circ} \mathrm{C}$ thermocline is at $400 \mathrm{~m}$ in winter (based on data in Levitus, 1982). Mean annual salinities across the Gippsland Shelf are normal marine and range from 35.2\% at $200 \mathrm{~m}$ depth to $35.5 \%$ at $50 \mathrm{~m}$ (Levitus, 1982). Mean annual interpolated data on dissolved oxygen values for the region suggest the shelf region is oxic, with values ranging from $4.9 \mathrm{ml}^{-1}$ at $450 \mathrm{~m}$ to $5.4 \mathrm{ml} \mathrm{l}^{-1}$ at $50 \mathrm{~m}$ (Levitus, 1982). The shelf area faces the Tasman Sea and, during summer, eddies of the warmer East Australian Current may extend southward from eastern Australia into the region, leading to the higher, summer, sea-surface temperatures recorded (Fig.1; Harris et al., 1987). During winter a dense cold saline water mass $(35.7 \%$ ) leaves the Bass Strait and travels northward along the shelf and sinks at the head of the Bass Canyon. Part of this water mass also travels east across the shelf and sinks into the Tasman Sea just beyond the position of the shelf break between 300 and $400 \mathrm{~m}$ (Godfrey et al., 1980; Tomczak, 1985). This is the 'Bass Strait Cascade', which is a density current that travels at speeds of up to $0.5 \mathrm{~m} \mathrm{~s}^{-1}$ below $200 \mathrm{~m}$. It is, therefore, an important local control on the facies at the shelf break at the head of the Bass Canyon.

The Gippsland region lies $500 \mathrm{~km}$ north of the Subtropical Convergence ocean front, which occurs around $45^{\circ} \mathrm{S}$ where the summer $15^{\circ} \mathrm{C}$ isotherm and winter $10^{\circ} \mathrm{C}$ isotherm outcrop on the surface (Martinez, 1994; Fig. 1).

A siliciclastic barrier system (Ninety Mile Beach, Fig. 2) separates the Gippsland Shelf from a series of brackish estuarine lakes (the Gippsland Lakes, Fig. 2) in the onshore Gippsland 


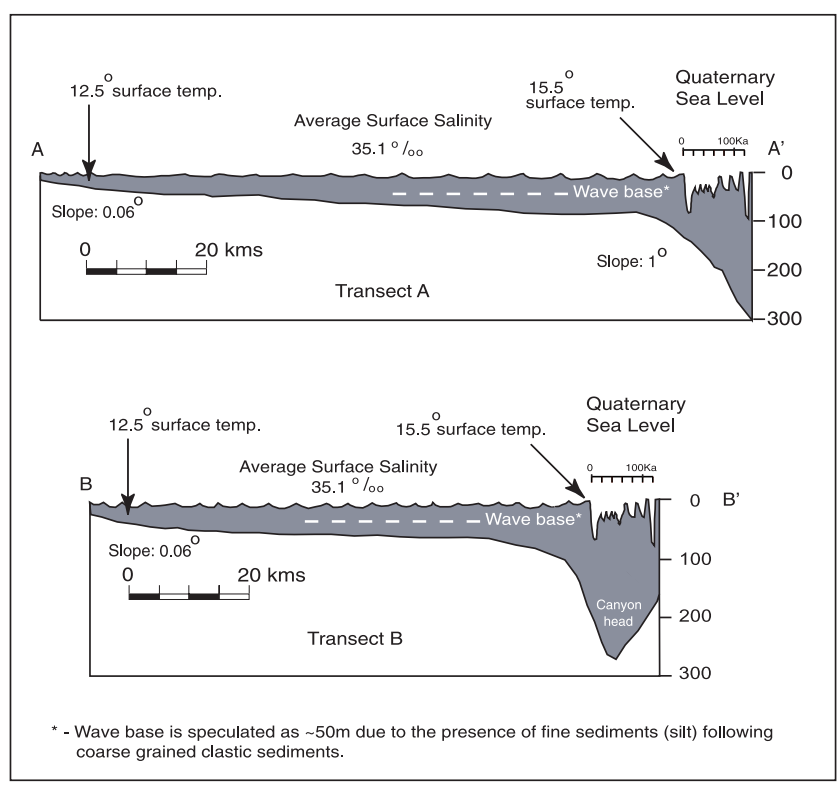

Fig. 3. The bathymetry of the two Gippsland Shelf transects, showing sea surface temperatures and salinities at time of collection (SeptemberOctober 1998). The Quaternary sea-level curve is superimposed on each transect (cf. James et al., 1992).

area. The lakes occupy an area of around $280 \mathrm{~km}^{2}$ with an average depth of less than $9 \mathrm{~m}$ (Apthorpe, 1980). The marine influence in these lakes is determined by their proximity to an artificially constructed sea entrance at Lakes Entrance (Fig. 2). These lakes are hyposaline and their salinity varies from $0.3-$ $5 \%$, where rivers enter the lakes, to $20-35 \%$ near Lakes Entrance (Apthorpe, 1980).

The siliciclastic content of the shelf varies between the two shelf transects: Transect A lithologies are dominated by bryozoan bioclasts with minor siliciclastics occurring from the middle to outer shelf, whereas the facies of Transect B contains abundant quartz right out to the outer shelf. The bryozoan facies is inferred to be comprised of modern bioclasts (the grab samples on this transect often yielded live bryozoans) and relict forms since bioclasts may show evidence of diagenetic alteration (such as limonite staining) as inferred by Jones \& Davies (1983) for much of the Bass Strait shelf areas. Transect B occurs directly offshore from the entrance to the Gippsland Lakes and the outlet of the Snowy River. These may be the source of some of this siliciclastic input, although it is likely that much of the siliciclastics on the Gippsland Shelf may be relict, having been reworked from outcropping strata on the sea bed or from quartz-rich material deposited on the shelf during Pleistocene lowstands.

It is possible to comment on the depth-related hydrodynamic interfacies within the Gippsland Basin, which differs from that of the neighbouring Otway Basin. The Otway cool-water carbonate shelf has been divided into abrasion depth $(=70 \mathrm{~m})$, swell wavebase $(=130 \mathrm{~m})$ and storm wave base $(=250 \mathrm{~m})$ by Boreen et al. (1993). The lithologies are dominated by quartz bioclastic gravels and hard substrates (within abrasion depth), coarse bioclastic sand (within swell wavebase) and fine biolcastic sand (within storm wave base). Using Boreen et al.'s (1993) criteria, it is inferred that the Gippsland Shelf has a shallower

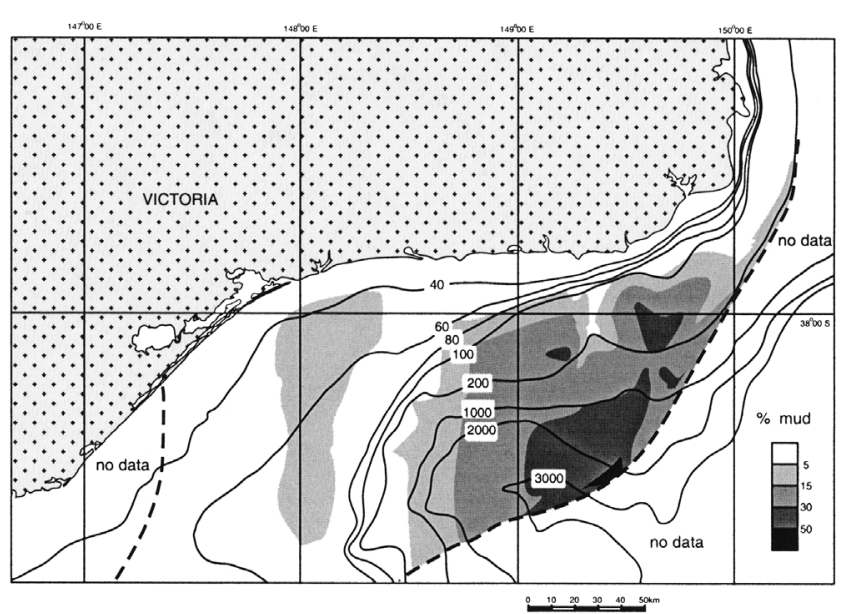

Fig. 4. The percentage of mud size sediments in the Gippsland Basin, using AGSO data from the Southern Surveyor (SS01/00) and data published in Jones \& Davies (1983).

swell and storm wave base due to the presence of finer-grained sediments at depths of below $50 \mathrm{~m}$ (Fig. 4). These lower energy conditions are interpreted to have been due to the fact that the Gippsland area is relatively more sheltered from Southern Ocean swells than the more exposed Otway margin.

This study is a useful modern analogue for Neogene palaeoenvironmental studies in southeast Australia since the Gippsland Shelf lithologies closely resemble the fine-grained lithologies such as marls and calcisiltites that predominate in southeast Australian Tertiary successions. For example, the modern Otway Shelf contains fine bioclastic sand to depths of $250 \mathrm{~m}$ (Boreen et al., 1993), while Miocene sequences in the Otway Basin contain marls and calcisiltites at middle shelf depths (Gallagher et al., 1999).

\section{FORAMINIFERA AND FACIES OF THE GIPPSLAND SHELF AND ESTUARINE LAKES}

The foraminifera and facies of the Gippsland Shelf and estuarine lakes will be described in four sections; the Gippsland estuarine lakes, the inner shelf $(0-50 \mathrm{~m})$, middle shelf $(50-100 \mathrm{~m})$ and outer shelf (100-200 m) to upper slope (>200 m).

\section{Gippsland estuarine lakes}

Lithology. The samples from within the lakes are silts and sands with relatively low carbonate contents. Bioclasts include foraminifera, mollusc fragments, gastropods and seagrass. The percentage of carbonate varies from $0.7 \%$ in Lake Wellington (GL197) to 35.5\% in Lake Victoria. Sample GL134 (just outside the lakes' entrance) consists entirely of quartz sand with minor bioclasts and a low $\mathrm{CaCO}_{3}$ percentage $(0.3 \%)$.

Benthic foraminifera. Samples GL4, GL118, GL18 and GL197 contain similar assemblages, dominated by the infaunal benthic rotaliid Ammonia beccarii, which may comprise over 95\% of the total foraminiferal assemblage. Sample GL18 contains the textulariid Eggerella advenum. GL145 preserves a relatively diverse assemblage dominated by $A$. beccarii with Quinqueloculina seminula, Elphidium and Discorbinella. At the entrance of the lakes, GL134 contains a different fauna, dominated by 
Quinqueloculina and Elphidium, while A. beccarii is rare, comprising $6 \%$ of the total assemblage. Standardized faunal diversity increases toward Lakes Entrance, from a low of 2 (Margalef Diversity Index, see Appendix 1) in the Gippsland Lakes to 5.7 at the entrance. Nearly $28 \%$ of the total fauna are relict forms in sample GL134 at Lakes Entrance; relict forms are absent in the other Gippsland Lakes samples. Since the samples analysed were not preserved in ethanol at the time of collection by Apthorpe (1980) no information on the live/dead ratio was obtained.

Planktonic foraminifera. No planktonic foraminifera occur in the six samples taken from the Gippsland Lakes.

\section{Inner shelf $(\mathbf{0}-\mathbf{5 0} \mathrm{m})$}

Lithology. Five samples were studied from the inner shelf region. The shallowest, at $19 \mathrm{~m}$ and $24 \mathrm{~m}$, are medium to coarse quartz sands with few bioclasts, with a low carbonate content $(c .7 \%)$ (Fig. 2). The deeper samples shelfward have increased carbonate percentages and are bioclast-rich molluscan-foraminiferal silty sands. The $\mathrm{CaCO}_{3}$ percentage reaches a maximum of $50 \%$ in the deepest of the inner shelf samples (Fig. 5).

Benthic foraminifera. The inner shelf foraminiferal assemblage almost entirely consists of benthic taxa. In the shallower samples, miliolids are dominant, including Quinqueloculina, Miliolinella and Triloculina. Of the benthic rotaliids, Ammonia beccarii, Elphidium and Discorbis are also common. Textulariids are rare in the shallowest samples but may comprise up to $20 \%$ of the entire assemblage in the deeper samples. Foraminiferal diversity increases with depth from 6 to 14 (Margalef Diversity). Relict foraminifera comprise from 13 to $34 \%$ of the total assemblage, and up to $10 \%$ of foraminifera were interpreted to have been living at time of collection (Figs 5 and 6).

Planktonic foraminifera. The inner shelf samples on average yield less than 1\% planktonic foraminifera (Figs 5 and 6).

\section{Middle shelf (50-100 m)}

Lithology. The ten middle shelf samples analysed have carbonate percentages ranging from $27 \%$ at $60 \mathrm{~m}$ depth on Transect B to $86 \%$ at $62 \mathrm{~m}$ depth on Transect A. The lithology of Transect A is characterized by poorly sorted bryozoan-molluscanforaminiferal silty carbonate sand, with abundant delicate branching, fenestrate and multilaminar forms of bryozoa. Other bioclasts include echinoid spines, mollusc fragments, foraminifera, gastropods and ostracods. A sample from $70 \mathrm{~m}$ water depth (MG17) differs slightly due to the presence of significant quartz. The shallowest middle shelf sample of Transect B is a carbonate-rich molluscan-foraminiferal silt. The facies on this transect becomes a carbonate-poor quartz-molluscanforaminiferal silty sand as it gets deeper. In general, the deepest middle shelf facies have higher carbonate values than the inner or shallower middle shelf facies due to the presence of abundant bryozoan bioclasts (Figs 5 and 6).

Benthic foraminifera. Miliolid taxa decrease in abundance with depth in the middle shelf (from $40 \%$ to $20 \%$ ), with common
Quinqueloculina and Miliolinella occurring in the shallowest middle shelf facies. Textulariids also decrease in abundance from $18 \%$ to $7 \%$. Benthic rotaliids are dominant, consisting primarily of Cibicides, Parrellina, Uvigerina, Elphidium and Dyocibicides. In the deeper mid-shelf samples, Lenticulina is also present. Diversity is relatively constant in the middle shelf, with an average index of 15 . Around $10 \%$ of the assemblage is interpreted to have been alive at time of collection, while relict forms are rare in the mid-shelf (Figs 5 and 6).

Planktonic foraminifera. The middle shelf samples yielded between $1 \%$ planktonic foraminifera in the shallower samples and $24 \%$ in the deeper samples. Globorotalia inflata dominates the planktonic foraminifera, with Globigerina bulloides also present (Figs 5 and 6).

\section{Outer shelf $(\mathbf{1 0 0}-\mathbf{2 0 0} \mathrm{m})$ to upper slope $(>\mathbf{2 0 0} \mathrm{m})$}

Lithology. The shallowest facies of the outer shelf samples of Transect A is similar to the deeper facies of the middle shelf (bryozoan-molluscan-foraminiferal silt to medium sand). The facies from 190 to $276 \mathrm{~m}$ depth are plankton foraminiferal-rich molluscan fine sands with 65 to $70 \%$ carbonate. Outer shelf facies of Transect B vary from a bryozoan-molluscanforaminiferal-quartz very fine to fine sand to bryozoalmolluscan-foraminiferal silt to medium sand, similar to the middle shelf facies of Transect A (Figs 5 and 6).

Benthic foraminifera. Few miliolids occur in the outer shelf region of Transect $\mathrm{A}$, although they constitute $15 \%$ of the total assemblage at $122 \mathrm{~m}$ water depth on Transect B, where Quinqueloculina is common. Textulariids comprise less than $10 \%$ of the fauna, becoming common in the deepest samples. The dominant textulariid taxa are Textularia, Gaudryina and Reophax. Cibicides and Uvigerina are the dominant outer shelf benthic rotaliids, with Astrononion, Anomalinoides, Bulimina and Discorbinella also present. The highest diversity shelf assemblage occurs in the deepest samples. A higher percentage of living foraminifera were obtained from Transect A (16-26\%) compared to Transect B $(c .10 \%)$. Relict foraminifera are rare in the outer shelf to upper slope samples with the exception of $122 \mathrm{~m}$ water depth on Transect B, where up to $12 \%$ relict forms occur (Figs 5 and 6).

Planktonic foraminifera. With increasing outer shelf to upper slope depths the percentage of planktonic foraminifera increases from 20 to $60 \%$. Globorotalia inflata is the dominant species, with lesser numbers of Globigerina bulloides, Globoquadrina dutertrei, Globorotalia truncatulinoides and Orbulina universa present (Figs 5 and 6).

\section{DISCUSSION}

Ammonia beccarii is the dominant species within the Gippsland estuarine lakes and it is also present in the shallow inner shelf samples. This taxon can tolerate low salinities of $2.7 \%$ (Apthorpe, 1980). Although not found in New Zealand, it is morphologically similar to Ammonia parkinsoniana, which dominates similar estuarine environments in New Zealand 
A. J. Smith et al.

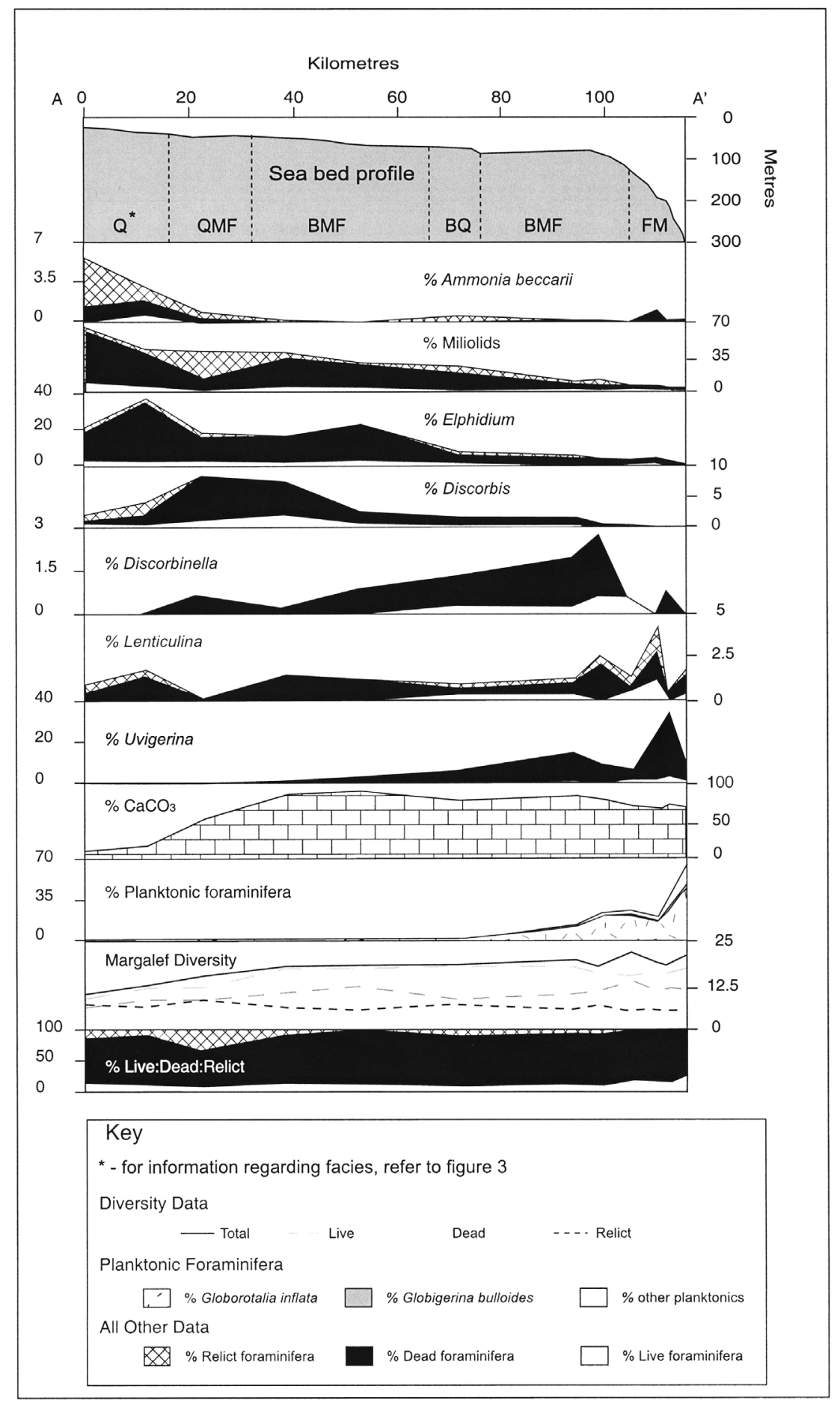

Fig. 5. The percentage abundance of selected foraminifera, their $\%$ live/dead/relict, total assemblage diversity data, lithology and $\%$ carbonate across transect A-A' (see Fig. 2 for locality).

(Hayward et al., 1999). Eggerella occurs in one sample. This taxon is also a common estuarine species found in New South Wales and Western Port Bay in Victoria. It inhabits shallow sandy substrates with seagrass (Albani, 1968; Bartels, 1979). For a more detailed description of the foraminiferal biofacies of the Gippsland Lakes see Apthorpe (1980).
Miliolids decrease in abundance with increasing depth across the shelf. Abundant relict miliolids occur in the samples shallower than $70 \mathrm{~m}$. Quinqueloculina, the dominant miliolid, is found today in lagoon inlet channels/intertidal zones to inner shelf areas in southeastern Australia (Yassini \& Jones, 1995). 
Foraminiferal biofacies of the Gippsland Shelf, southeastern Australia

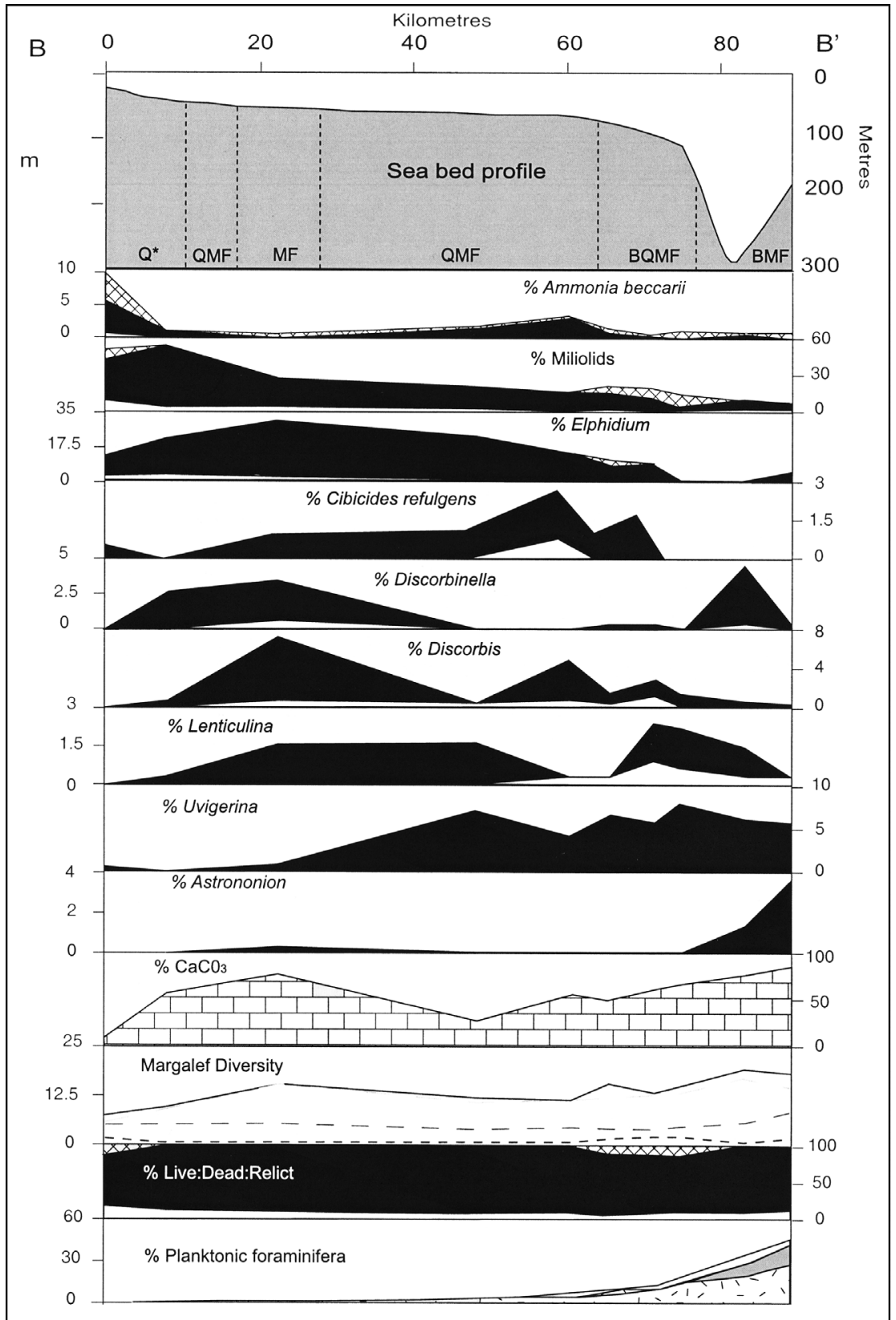

Fig. 6. The percentage abundance of selected foraminifera, their $\%$ live/dead/relict, total assemblage diversity data, lithology and $\%$ carbonate across transect B-B' (for key see Fig. 5, for location of transect see Fig. 2).

Elphidium is common from the inner to mid-shelf samples with minor relict forms. This genus is rarely found deeper than $70 \mathrm{~m}$. This is a similar distribution to that shown in various studies around the southeastern Australian coast, where the species is common in depths of less than $100 \mathrm{~m}$ (Parr, 1945; Collins, 1953; 1973; Albani, 1968; Johnson \& Albani, 1973; Bartels, 1979; Apthorpe, 1980; Cann \& De Deckker, 1981; Cann \& Gostin, 1985; Cann et al., 1988; Yassini \& Jones, 1995).

Discorbis is also most commonly found in the shallower shelf samples, and this genus is generally regarded to be an inner shelf indicator (Murray, 1991). Discorbinella and Lenticulina are present across this part of the Gippsland Shelf becoming common in the middle to outer shelf.

The epifaunal Cibicides refulgens occurs (living) from inner to middle shelf depths. This taxon occurs on the modern Otway Shelf at depths of between $30 \mathrm{~m}$ and $70 \mathrm{~m}$, which differs significantly from the distribution documented by Murray (1991) in the Southern Ocean region, where it is recorded from depths between $136 \mathrm{~m}$ and $950 \mathrm{~m}$. This species is also found in Broken Bay and Port Hacking at depths of $5 \mathrm{~m}$ and $6 \mathrm{~m}$ respectively (Albani, 1968; Johnson \& Albani, 1973), thereby giving this taxa a wide depth distribution. The distribution of this taxon is substrate controlled. It occurs most commonly on bioclastic 
sand substrates, where it can attach itself onto grains of sand or bioclasts, allowing it to survive high energy environments. The distribution of C. refulgens is the opposite to that of Uvigerina on Transect B (Fig. 6).

Uvigerina increases in abundance with depth and is most abundant at the shelf break in fine-grained plankton-rich sands and silts. An abundance of this taxon is often associated with local upwelling at shelf breaks (Gupta \& Srinivasan, 1992; Gupta \& Marchain-Castillo, 1993). The genus Uvigerina is known to inhabit low-energy, infaunal microhabitats rich in organic matter, where its presence may relate to a high continuous flux of organic matter onto the sea floor, often associated with reduced bottom water oxygenation (Thomas \& Gooday, 1996). Gibbs et al. (1986) measured the dissolved oxygen content of the water column of a locality off the Gippsland Shelf southeast of the area sampled (latitude $38^{\circ} 47^{\prime} \mathrm{S}$, longitude $148^{\circ}$ $\left.52^{\prime} \mathrm{E}\right)$. At this locality it can be seen that there is a decrease in dissolved oxygen from $5.0 \mathrm{ml} \mathrm{l}^{-1}$ at the surface to $4.5 \mathrm{ml}^{-1}$ at $200 \mathrm{~m}$, the depth at which Uvigerina is most abundant in this study.

The carbonate content is low in the inner shelf samples. This is caused by dilution of coarse-grained siliciclastics from the local coastal barrier facies. The carbonate percentage increases with depth and is directly related to an increase in bryozoan bioclasts. Planktonic foraminifera increase in abundance with depth, particularly below $70 \mathrm{~m}$, reaching a maximum at the shelf break $(>200 \mathrm{~m})$, this abundance probably represents higher organic productivity at the head of the Bass Canyon.

The maximum assemblage diversity values and percentage of living foraminifera representing the optimum environmental conditions for abundant foraminifera occur on the upper slope just below the shelf break $(>200 \mathrm{~m})$. It is inferred that the high proportion of relict foraminifera within the inner shelf siliciclastic-rich biofacies is possibly a result of reworking by wave action of Quaternary fossilized forms (see below).

\section{FORAMINIFERAL LIVE/DEAD RATIOS AND PRODUCTION RATES}

When data on recently living and recently dead assemblages are available from the same sample, it is possible to estimate the different rates of production of the component species using the calculation outlined in Appendix 2. Production can be defined as the number of tests added to an area of sea floor during a specific period of time. A living assemblage, through life processes such as reproduction and death, gives rise to an 'ideal' dead assemblage which, in turn, may be altered by post-mortem changes to give the final assemblage preserved in the sediments (Murray, 1991). Estimates of faunal productivity of several species in this study (see Appendix 2) suggest it is unlikely that there are differential production rates greater than 10 or 12 times between species. Rates differing by these amounts are probably caused by post-mortem influences such as mixing, bioturbation, transportation and destruction of tests (Murray, 1991).

With the exception of sample MG29, the estimated faunal productivity of all species is similar $(<10)$ suggesting most of the modern Gippsland Shelf foraminiferal assemblages have not been significantly reworked. In MG29 (from a depth of $43 \mathrm{~m}$ ), Quinqueloculina yields production rates 17 times that of the species Nonion victoriensis. Thus, in this particular sample, significant recent reworking has occurred to create the final assemblage.

\section{RELICT FORAMINIFERA}

A significant proportion of the foraminiferal assemblage is inferred to be of fossil or relict specimens. Many of the relict forms are interpreted to have undergone sub-aerial alteration. Only samples from less than $150 \mathrm{~m}$ water depth will contain in situ relict forms, as it is inferred that these relict forms may be a product of the last glacial maximum (c.19000 years ago (Bard et al., 1990)), during which the sea-level was between 120 and $150 \mathrm{~m}$ below present day (Chappell \& Shackleton, 1986), exposing most of the Gippsland Shelf. This allowed reworking and sub-aerial weathering of pre-existing shelf and marine lagoonal sediments. Figure 2 illustrates the Quaternary sea-level curve plotted to scale on the shelf transects.

Inner shelf samples yield up to $34 \%$ relict specimens, whereas middle and outer shelf samples yield less than $12 \%$ relict specimens. These values represent a sample bias in shallow water environments where more relict foraminifera are to be expected compared to deeper water facies (where relict specimens are rare) since the sampled areas may have remained below sea-level at times of lower sea-level (Li et al., 1996a,b). However, samples from water depths $>100 \mathrm{~m}$ may contain foraminifera which are the same age as the relict forms and from the same depositional regime but not identified as relict due to a lack of alteration.

The suborder with the most relict forms is the Milioliina, with Quinqueloculina, Miliolina and Triloculina being the most common relict genera. These taxa inhabit shallow normal marine lagoon to inner shelf environments. A high abundance of relict foraminifera in the shallower shelf facies is a consistent feature around the southern Australian continental margin (Li et al., 1999). Figure 6 shows the results of relict and recently dead assemblages plotted on the ternary diagrams of Murray (1973). The pattern of results is similar to that of Li et al., (1996a,b), where the relict forms are derived from a past marine lagoonal setting and incorporated into Recent open shelf biofacies ( $\mathrm{Li}$ et al., 1996a,b).

\section{STATISTICAL ANALYSES OF FORAMINIFERAL ASSEMBLAGES}

\section{Correspondence analysis}

Correspondence analysis (CA) is an eigenvector method which allows the projection of a large multivariate cloud of points (samples, parameters or both) into a very reduced space (defined by the factor axes) while conserving the major part of the structured, meaningful information (Hennebert \& Lees, 1991). The result is a two-dimensional graph, where similar samples or parameters (or both) are nearest each other and those which are most dissimilar are furthest apart. CA calculates the variation (as a percentage) represented by each axis, and assigns a Relay Index (RI) to each sample or component; these values are rescaled such that the range of RIs lies between 0 and 100 (Pickard, 1994).

The method is useful in detecting environmentally important trends in foraminiferal assemblage data. If a unidimensional 


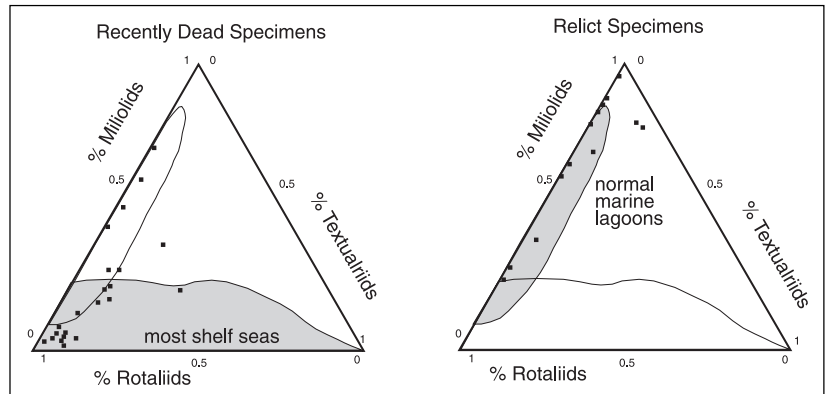

Fig. 7. Ternary plots of recently dead and relict specimens, consisting of the three suborders: miliolids, textulariids and rotaliids (cf. Murray, 1973). Most sample points plot in the environmental categories of 'most shelf seas' and 'normal marine lagoons' of Murray (1973).

variation trend such as a depth relay exists in the dataset, projection of the results of CA onto a factorial plane (defined by the first and second CA axes) should produce an Arch effect or Guttman effect (Pickard, 1994). CA has been applied successfully to modern and ancient carbonate facies analysis by Melguen (1974) and Hennebert \& Lees (1991), to Carboniferous limestones by Pickard (1994) and to Carboniferous foraminiferal studies by Gallagher (1992). The computer packages utilized to carry out the analysis on this data - SedUTIL (used to store the data) and AFCal (a correspondence analysis package) - were created by Lees (1989)

\section{Results of correspondence analysis}

Figure 8 represents the correspondence analyses results for the 28 shelf samples studied and Figure 9 is a CA plot of the parameters. The percentage abundance of 61 parameters in each of the 28 samples was included in the analysis: 44 were benthic foraminiferal taxa, 11 were planktonic foraminiferal taxa. Other parameters include the total percentages of the suborders, 'undifferentiated foraminifera' and $\% \mathrm{CaCO}_{3}$.

Before beginning analysis on the CA data, the proportion of inertia of each of the axes must be considered. The calculated inertia of the three axes is $38.0 \%, 26.4 \%$ and $9.7 \%$ respectively for axes one, two and three, totalling $74.1 \%$. If values greater than $30 \%$ are obtained for the first axis, or if the total statistical variation accounted for the three axes is over $50 \%$, then the results of the analysis are useful and a statistically significant arched plot is obtained (Gallagher, 1992).

The scatter of points on the CA plot is clearly related to sample depth, with the lake samples plotted on the left side of the graph, followed by the inner shelf samples, the middle shelf samples and the outer shelf to upper slope samples. Water depth may also control the nutrient availability in the bottom water. The lakes samples contain a significantly different assemblage to the shelf samples and this causes stretching of the shower of points on the left side. The results for the shelf samples represent a continuous relay from the inner to outer shelf biofacies. Although depth seems to be the dominant control on the distribution of sample and parameter points on the correspondence analyses plots, there are other factors, such as lithology, that also control their distribution.

Samples from $70 \mathrm{~m}$ (Transect A) and $78 \mathrm{~m}$ (Transect B) contain similar foraminiferal assemblages with RIs of 85.8 and 85.7 (Fig. 8). Samples from $120 \mathrm{~m}$ (Transect A) and $263 \mathrm{~m}$

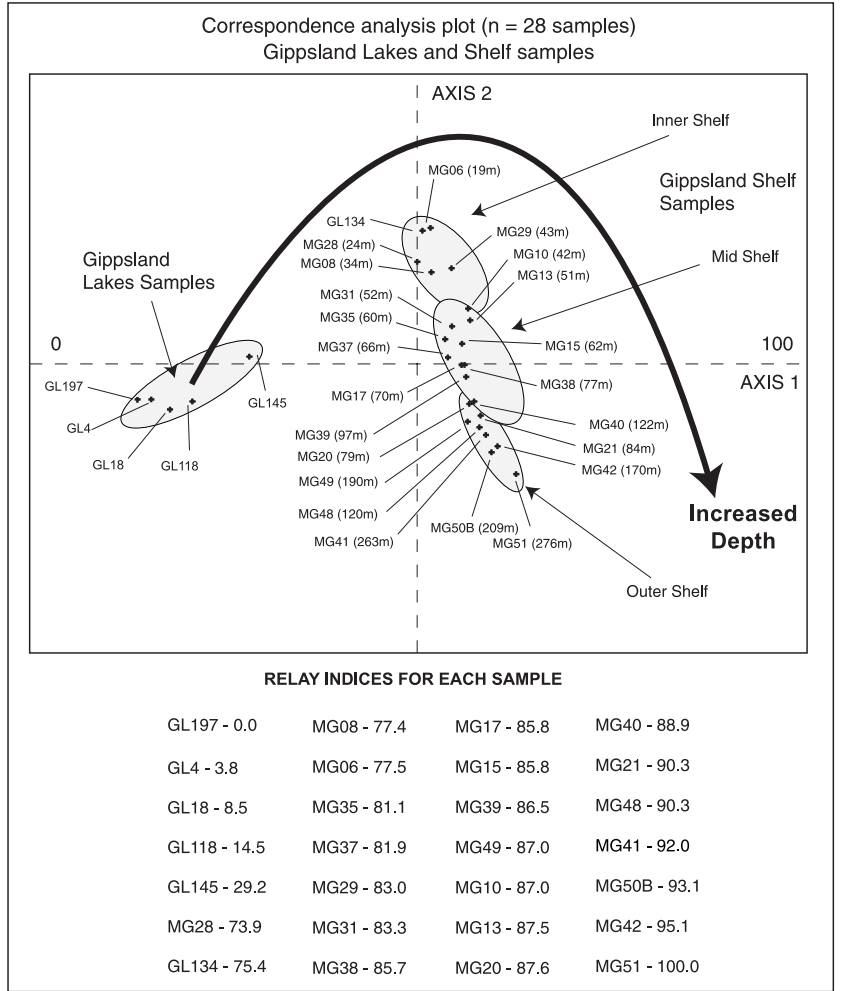

Fig. 8. Results of the correspondence analysis of 28 samples from the Gippsland Shelf and Lakes. The parameters used for this analysis are listed in Figure 9.

(Transect B), despite differing water depth, yield similar assemblages, with RIs of 90.3 and 92.0, respectively. Both samples are of bryozoan-molluscan-foraminiferal silt to medium sand.

The distribution of parameters on Figure 9, although principally controlled by depth, is also related to salinity variations and $A$. beccarii and Eggerella plot away from the main group of parameters. Eggerella is restricted to the relatively euryhaline Gippsland Lakes. A. beccarii is rare on the inner shelf, but may comprise up to $95 \%$ of the Gippsland Lakes foraminiferal assemblages.

For interpretative purposes the CA plot can be subdivided into Gippsland Lakes, inner shelf, middle shelf and outer shelf parameter groups (Fig. 9)

The inner shelf assemblage of Figure 9 contains Nonion, Quinqueloculina, Triloculina and Elphidium. Discorbis and C. refulgens plot between the inner and middle shelf clusters. Discorbinella and Lenticulina plot between the middle and outer shelf clusters. Similar shelf distributions for these taxa in southern and eastern Australia were noted by Yassini \& Jones (1995), Murray (1991) and Albani (1978). The \% $\mathrm{CaCO}_{3}$ parameter plots in the middle shelf cluster, where carbonate values are highest due to the presence of abundant bryozoans seaward of the inner shelf siliciclastic facies.

The total percentage of benthic rotaliids (BR) plots as an outlier from the main cluster. This is consistent with the observation that rotaliids have a wide environmental distribution from marine lakes and inner to outer shelf environments (Murray, 1991). 


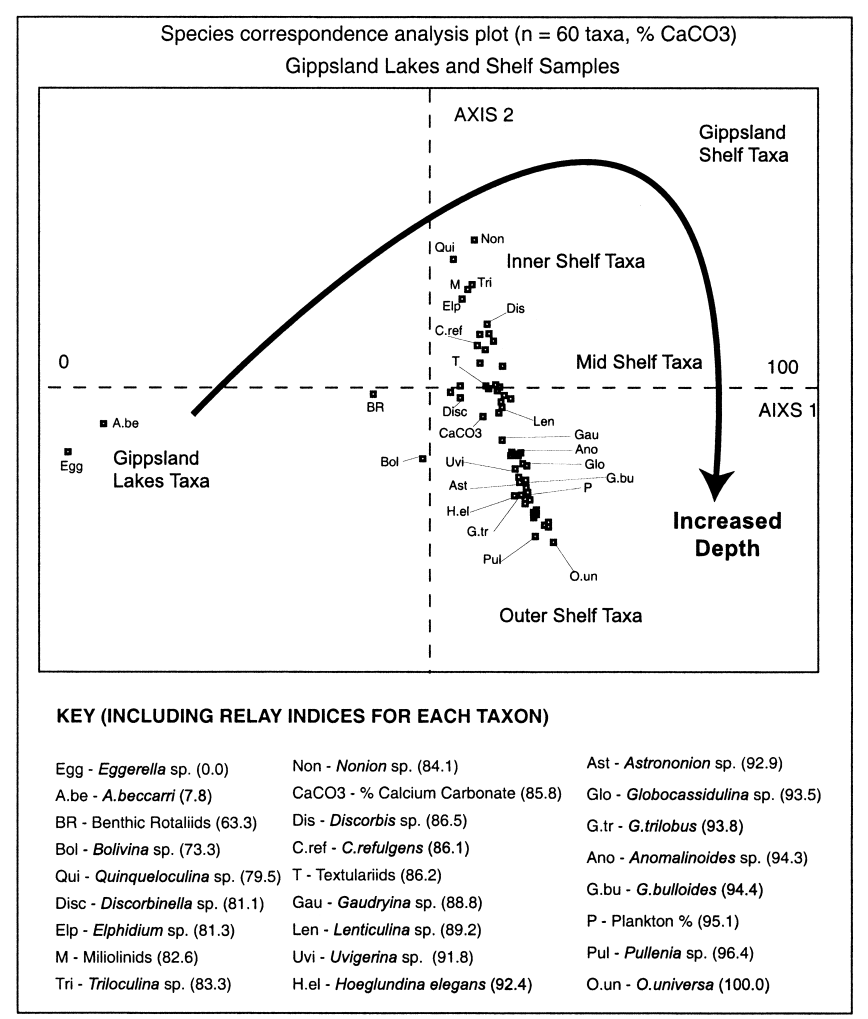

Fig. 9. Results of the correspondence analysis of 61 parameters in 28 samples from the Gippsland Shelf and Lakes. The samples used for this analysis are listed in Figure 8.

Uvigerina and Astrononion plot in the outer shelf cluster. These typically deep water forms also prefer finer-grained substrates since both are infaunal (Murray, 1991). Other species that plot in the outer shelf cluster are Hoeglundina elegans, which occurs in the outer shelf to the lower slope (Taylor \& Mee, 1970; Murray, 1991) and Pullenia, which is also a common outer shelf species (Yassini \& Jones, 1995; Murray, 1991).

All 11 species of planktonic foraminifera, together with the value for the total percentage of plankton, plot in the outer shelf cluster. This is consistent with the quantitative observations that plankton percentages increase with depth.

\section{SUMMARY OF THE FORAMINIFERAL DISTRIBUTION OF THE GIPPSLAND SHELF AND LAKES}

Figure 10 summarizes the idealized distribution of the most common benthic foraminiferal species on the Gippsland Shelf, incorporating the transect quantitative data and correspondence analyses results. The full distributional data are based on the percentage of that taxon in the total assemblage. In addition, the occurrence of foraminifera interpreted to have been living at the time of collection is shown. No data concerning living assemblages were obtained from the Gippsland Lakes samples.

It is clear from the distribution of inferred living forms that significant reworking by wave action or other processes (such as bioturbation) of the Gippsland Shelf assemblages has not occurred, since the total faunal assemblage data (i.e. total living + recently dead + relict forms(rare)) is similar to the distribution of the live forms. There are, however, important exceptions. For example, live forms of Cibicides mediocris only occur from the middle to outer shelf, suggesting that while it is found in inner shelf biofacies this epifaunal taxon has an optimum depth distribution deeper than $50 \mathrm{~m}$ (although this is also reflected in the full assemblage data). The textulariid Textularia sagittula is found living in the inner shelf biofacies yet its full distribution ranges into the middle and outer shelf, where recently dead and relict forms occur.

The distribution of living foraminiferal assemblages may be seasonal and as we only collected samples at one particular time (September-October), this limits our interpretations of living forms. This temporal variation is countered by analyses of the full foraminiferal assemblage data (especially incorporating the live plus recently dead forms) which average out inter-annual variations. This is the most useful type of comparative data required to interpret Tertiary fossil assemblages in southeastern Victoria. Still, it is very important to identify recent living assemblages to understand faunal productivity and to interpret the taphonomic processes that ultimately lead to neritic foraminiferal deposits.

As summarized above, the distribution of relict foraminifera on the Gippsland Shelf is confined mainly to inner and middle shelf depths. This pattern is illustrated on Figure 10. With the exception of Uvigerina bassensis, most recorded relict foraminifera on the Gippsland Shelf are those commonly found living at inner to middle shelf depths. No relict 'true' outer taxa were recorded. During Pleistocene lowstand times regressive events exposed much of the shelfal areas, principally reworking preexisting inner to middle shelf faunas. At outer shelf depths a few relict middle shelf taxa occur; these are inferred to have been transported into the outer shelf during lowstand times.

\section{CENOZOIC PALAEO-ENVIRONMENTAL SIGNIFICANCE OF THE GIPPSLAND SHELF FORAMINIFERAL FAUNAS}

Figure 11 summarizes the biostratigraphic ranges of 43 Gippsland Shelf foraminiferal taxa (listed in Fig. 10), based on stratigraphic studies of the Cenozoic successions of southeast Australia (northern Tasmania, the Otway Basin and the Gippsland Basin). In addition, cosmopolitan and (semi)endemic taxa are distinguished. The term (semi-)endemic here refers to Gippsland Shelf foraminiferal taxa that are either confined to shelfal areas in southern Australia, New Zealand and the southwest Pacific or even in South America (sensu Li et al., 1996c).

Two-thirds of the modern Gippsland Shelf fauna listed are cosmopolitan species. These taxa show similar depth distributions to those listed in Murray (1991) for other shelf regions. The remaining (semi-)endemic taxa are, therefore, only suitable for regional palaeo-environmental studies. It is clear from Figure 11 that the present foraminiferal distribution evolved primarily since Early Miocene times, with most faunal elements present by the Late Miocene. Thus, not surprisingly, the modern Gippsland Shelf foraminiferal biofacies distribution can best be used as an analogue for Neogene palaeo-environmental studies in southeast Australia. The longer ranging taxa (i.e. those that first occur prior to the Miocene) are primarily middle to outer shelf forms and are also mainly cosmopolitan species. It is suggested that the modern deeper living forms are more conservative since they evolved in relatively lower stress 
Foraminiferal biofacies of the Gippsland Shelf, southeastern Australia

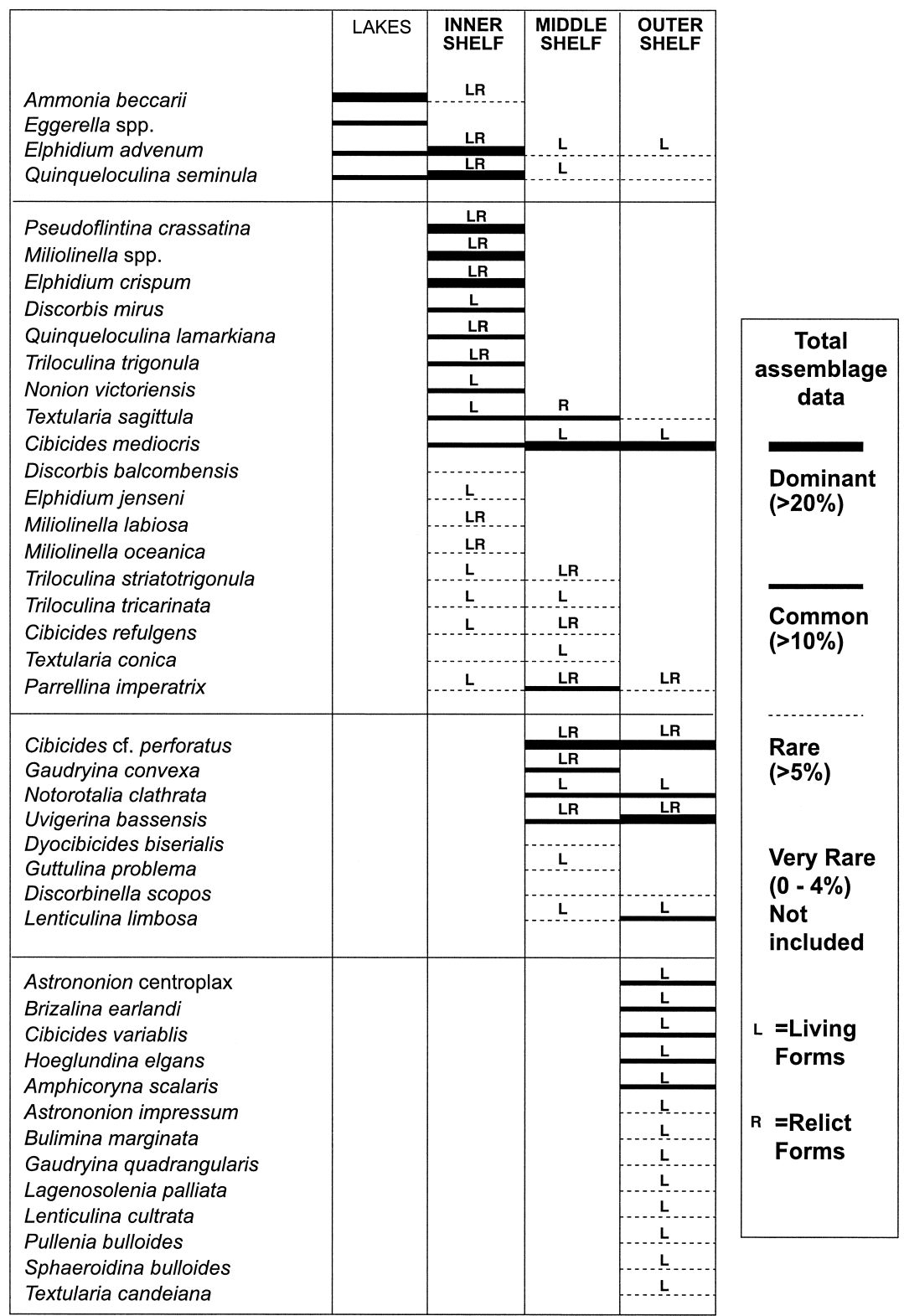

Fig. 10. An idealized summary of the distribution of benthic foraminifera from the Gippsland Lakes to the outer Gippsland Shelf based on the results of the quantitative foraminiferal analysis and the correspondence analysis (Figs 8, 9). Note that the bars represent the relative abundance of particular taxa from the total assemblage data ( $\%$ live/dead/relict), species of less than $5 \%$ not included.

mesotrophic to eutrophic environments compared to inner shelf faunas whose ecological niches would be markedly affected by sea-level and temperature variations in oligotrophic zones of constant wave abrasion.

\section{CONCLUSIONS}

This study integrates foraminiferal and biofacies studies of Recent sediments from the temperate Gippsland Shelf and associated marine lakes in southeast Australia, including lithological analyses and interpretations of live/dead foraminiferal assemblages and draws the following conclusions.

- Three types of distributional data were collected for the foraminiferal assemblage in each sample: forms interpreted to have been alive at time of collection (= live forms); forms with no evident protoplasm at time of collection nor any visible diagenetic alteration (= recently dead forms) and relict forms.

- The silt and sands of the euryhaline Gippsland Lakes contain abundant Ammonia beccarii and Eggerella advenum, with lesser numbers of Quinqueloculina, Elphidium and Discorbinella. No data on live/dead ratios were obtained from the lakes.

- The inner shelf biofacies is dominated by medium to coarse quartz-rich sands with minor bioclasts grading to bioclastic molluscan-foraminiferal silty sands. Living, relict and recently dead miliolids dominate the fauna, with common Ammonia, Elphidium and Discorbis and rare planktonic forms. 


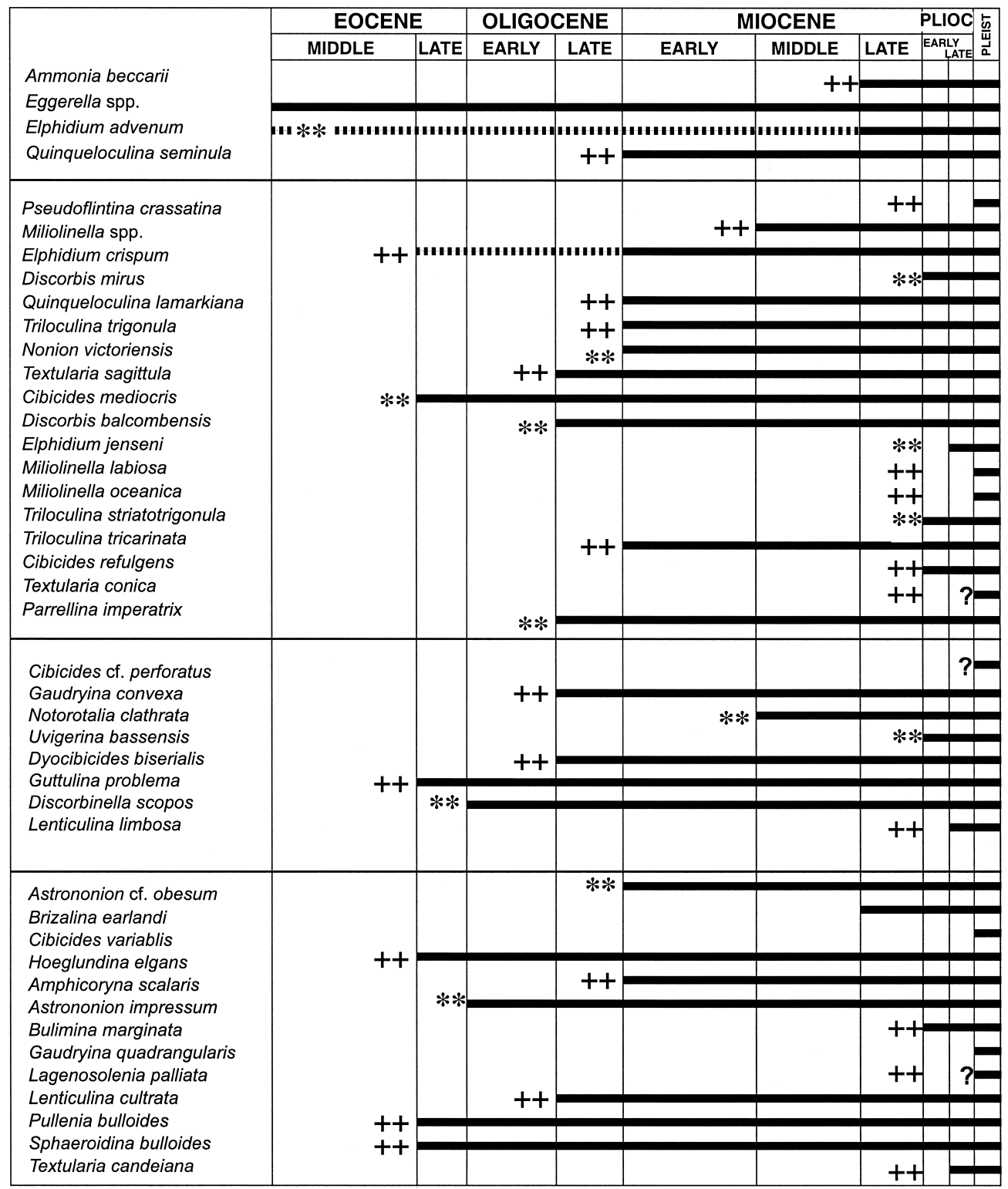

++ Cosmopolitan species $* *$ Semi-endemic species sensu Li et al. (1996c) ? Full range unknown

Fig. 11. The Cenozoic biostratigraphic ranges of the Gippsland Shelf and Lakes benthic foraminifera listed in Figure 10. The ranges for the taxa are for the Gippsland, Otway and Tasmanian Cenozoic strata, based on data from Parr (1941, 1945), Taylor et al. (1972), Quilty (1974, 1982), Li et al. (1996c), Li \& McGowran (1997), Gallagher et al. (1999), Gallagher \& Holdgate (1996, 2000) and Holdgate \& Gallagher (1997). Note the dashed lines refer to New Zealand ranges from Hayward et al. (1999). The biogeographic data were obtained from Li et al.(1996c) and Murray (1991).

- The bryozoan carbonate-rich bioclastic silts and silty sand facies of the Gippsland middle shelf (50-100 m depth) are characterized by common planktonic foraminifera, Cibicides, Parrellina, Elphidium and Lenticulina; up to $10 \%$ of the faunal assemblages are relict.

- Bryozoan plankton-rich silts and fine sands typify the outer shelf to upper slope facies on the Gippsland Shelf. A diverse fauna, with rare miliolids and common Textularia, Gaudryina, Uvigerina, Bulimina, Anomalinoides and Astrononion, occurs in this biofacies. Relict forms are rare in the outer shelf biofacies. Planktonic foraminifera and the infaunal Uvigerina are most abundant at the shelf break (where faunal diversity is highest), due to local upwelling at the head of the Bass Canyon.

- Estimates of faunal production rates from live/dead ratios suggest that the Recent (non-relict) fauna of the Gippsland Shelf has not been significantly mixed by wave and/or bioturbation processes. This conclusion, is also confirmed in the full assemblage data across the shelf, where the distribution of living forms is similar to the distribution of the total assemblage data. It is important to identify recent living assemblages to understand faunal productivity and to 
interpret the taphonomic processes that ultimately lead to neritic foraminiferal deposits.

- Most relict foraminifera recorded occur in the inner shelf areas, with minor relict forms in the middle to outer shelf. This pattern is similar to other shelf regions in Australia, where shelf areas were exposed during the Last Glacial Maximum, reworking shelf facies shallower than $100 \mathrm{~m}$ depth.

- Sediment characteristics suggest that the Gippsland Shelf has a shallower wave base than the neighbouring Otway Shelf. The Otway Shelf contains fine bioclastic sand to depths of $250 \mathrm{~m}$, while the Gippsland Shelf contains fine-grained sediments just below $50 \mathrm{~m}$. The shallower, lower energy lithologies occur on the Gippsland Shelf since it is more protected than the Otway Shelf from the Southern Ocean swells.

- Correspondence analyses of the 61 parameters (percentage abundance of foraminifera and $\% \mathrm{CaCO}_{3}$ ) in 28 samples studied yielded a clear depth-related pattern, differentiating Gippsland Lakes, inner, middle and outer shelf assemblages. The analyses also showed a clear, lithological control on the fauna, where samples from different depths and similar lithology yielded similar Relay Index scores.

- Over two-thirds of the modern Gippsland Shelf fauna in this study are cosmopolitan species, the remaining are (semi-) endemic taxa suitable for regional palaeo-environmental studies. Most species of the foraminiferal assemblages evolved since Early Miocene times, with most of them present by the Late Miocene. Thus, the modern Gippsland Shelf foramin- iferal biofacies distribution is the best analogue for Neogene palaeo-environmental studies in southeast Australia. The long ranging pre-Miocene taxa are middle to outer shelf cosmopolitan forms that are inferred to have been more conservative since they evolved in relatively lower stress mesotrophic to eutrophic environments, compared to inner shelf faunas whose ecological niches were markedly affected by sea-level and temperature fluctuations in zones of constant wave action and oligotrophy.

The foraminiferal and facies analogues of this study on the Gippsland Shelf will greatly improve palaeo-environmental analyses of Gippsland and Otway Neogene sedimentary successions. Improvements in palaeo-environmental analyses will lead ultimately to a better understanding of the evolution of the neritic realm in southeastern Australia, an area facing the evolving Southern Ocean during the Cenozoic.

\section{ACKNOWLEDGEMENTS}

This study was supported by a grant from the Australian Research Council. The authors thank Marjorie Apthorpe for providing the six Gippsland Lakes samples and the crew of the RV Franklin for their help with collecting the Gippsland Basin samples during September to October, 1998.

\section{Manuscript received 8 June 2000 \\ Manuscript accepted 14 September 2001}

\section{APPENDIX 1 \\ Margalef Diversity Index}

$D=S-1 / \log N$,

where $D$ is the diversity, $S$ is the number of species and $N$ is the number of specimens.

This coefficient more accurately relates each sample to one another as some samples have a different number of specimens picked than others (from Brenchley \& Harper, 1998).

\section{APPENDIX 2}

When data on recently living and recently dead assemblages are available from the same sample it is possible to estimate the different rates of production of the component species using the following method, as described by Murray (1991).

- Disregard species with an abundance of less than 4\% (to eliminate rare occurrences).

- For the species with the smallest percentage of dead compared with the percentage of living, let the production rate be taken as $\times 1$ (i.e. the annual production $=$ standing crop).

- From this the number of individuals equal to $1 \%$ of the dead assemblage can be calculated because the percentage living $=$ number of individuals equivalent to the percentage dead, e.g. living $50 \%$, dead $10 \%$, therefore 50 individuals $=10 \%$ dead, $1 \%$ dead $=5$ individuals.

- Multiply the percentage dead of all other species in the sample by this amount.

- Divide the number of dead individuals by the living percentage for each species to give the rate of production.

\begin{tabular}{|c|c|c|c|c|}
\hline & Live $(\%)$ & Dead $(\%)$ & & Production $(x)$ \\
\hline SAMPLE MG51 (276 m) & & & $1 \%=0.6$ inds & \\
\hline Uvigerina bassensis & 1.2 & 8.0 & 4.80 & 4.00 \\
\hline Textularia sagittula & 2.4 & 4.0 & 2.40 & 1.00 \\
\hline SAMPLE MG50B (209 m) & & & $1 \%=0.15$ inds & \\
\hline Cibicides mediocris & 1.3 & 8.5 & 1.30 & 1.00 \\
\hline Uvigerina bassensis & 3.9 & 30.8 & 4.62 & 1.18 \\
\hline
\end{tabular}

Table A2.1. 
A. J. Smith et al.

\begin{tabular}{|c|c|c|c|c|}
\hline & Live $(\%)$ & Dead $(\%)$ & & Production $(x)$ \\
\hline SAMPLE MG49 (190 m) & & & $1 \%=0.46$ inds & \\
\hline Cibicides mediocris & 2.3 & 12.8 & 5.89 & 2.56 \\
\hline Uvigerina bassensis & 1.5 & 22.7 & 10.44 & 6.96 \\
\hline Lenticulina limbosa & 1.2 & 2.6 & 1.20 & 1.00 \\
\hline Parellina imperatrix & 1.5 & 6.1 & 2.81 & 1.87 \\
\hline SAMPLE MG48 (120.5 m) & & & $1 \%=0.19 \mathrm{inds}$ & \\
\hline Cibicides mediocris & 1.4 & 7.6 & 1.44 & 1.03 \\
\hline Uvigerina bassensis & 1.1 & 5.9 & 1.10 & 1.00 \\
\hline Cibicidoides perforatus & 3.4 & 25.1 & 4.77 & 1.40 \\
\hline SAMPLE MG21 (84 m) & & & $1 \%=0.08$ inds & \\
\hline Miliolinella spp. & 0.3 & 5.8 & 0.46 & 1.55 \\
\hline Cibicides mediocris & 1.8 & 22.9 & 1.80 & 1.00 \\
\hline SAMPLE MG20 (79 m) & & & $1 \%=0.37 \mathrm{inds}$ & \\
\hline Miliolinella spp. & 1.3 & 3.5 & 1.30 & 1.00 \\
\hline Cibicides mediocris & 2.5 & 20.7 & 7.66 & 3.06 \\
\hline Elphidium crispum & 0.3 & 5.4 & 2.00 & 6.66 \\
\hline Parellina imperatrix & 0.3 & 4.7 & 1.74 & 5.80 \\
\hline Uvigerina bassensis & 0.9 & 13.7 & 5.07 & 5.63 \\
\hline SAMPLE MG17 $(70 \mathrm{~m})$ & & & $1 \%=0.2 \mathrm{inds}$ & \\
\hline Sigmoilina australis & 0.3 & 5.8 & 1.16 & 3.87 \\
\hline Triloculina spp. & 0.6 & 4.4 & 0.88 & 1.47 \\
\hline Cibicides mediocris & 2.3 & 23.3 & 4.66 & 2.03 \\
\hline Elphidium crispum & 0.9 & 4.4 & 0.88 & 0.98 \\
\hline Parellina imperatrix & 0.3 & 5.8 & 1.16 & 3.87 \\
\hline Uvigerina bassensis & 0.3 & 6.5 & 1.30 & 4.33 \\
\hline SAMPLE MG15 (62 m) & & & $1 \%=0.3 \mathrm{inds}$ & \\
\hline Miliolinella spp. & 1.5 & 13.6 & 4.08 & 2.72 \\
\hline Triloculina striatotrigonula & 0.6 & 3.0 & 0.90 & 1.50 \\
\hline Cibicides mediocris & 0.3 & 8.4 & 2.52 & 8.40 \\
\hline Dyocibicides spp. & 0.6 & 3.1 & 0.93 & 1.55 \\
\hline Elphidium crispum & 1.8 & 16.7 & 5.01 & 2.78 \\
\hline Elphidium jenesi & 0.9 & 3.0 & 0.90 & 1.00 \\
\hline Parellina imperatrix & 0.9 & 4.3 & 1.29 & 1.43 \\
\hline Textularia sagittula & 0.6 & 6.5 & 1.95 & 3.25 \\
\hline SAMPLE MG13 (51.5 m) & & & $1 \%=0.33$ inds & \\
\hline Miliolinella spp. & 2.4 & 9.1 & 3.00 & 1.25 \\
\hline Quinqueloculina lamarkiana & 0.6 & 5.1 & 1.68 & 2.81 \\
\hline Triloculina trigonula & 1.2 & 5.5 & 1.82 & 1.51 \\
\hline Discorbis mirus & 1.8 & 5.5 & 1.80 & 1.00 \\
\hline Elphidium crispum & 0.9 & 12.5 & 4.13 & 4.58 \\
\hline Textularia sagittula & 1.2 & 10.1 & 3.33 & 2.78 \\
\hline SAMPLE MG10 (42.5 m) & & & $1 \%=0.14 \mathrm{inds}$ & \\
\hline Discorbis mirus & 1.0 & 7.1 & 1.00 & 1.00 \\
\hline Elphidium crispum & 2.0 & 14.9 & 2.09 & 1.04 \\
\hline Textularia sagittula & 0.7 & 15.6 & 2.18 & 3.12 \\
\hline SAMPLE MG08 (34 m) & & & $1 \%=0.31 \mathrm{inds}$ & \\
\hline Miliolinella spp. & 1.4 & 10.2 & 3.16 & 2.26 \\
\hline Quinqueloculina arenata & 2.5 & 21.2 & 6.57 & 2.63 \\
\hline Quinqueloculina lamarkiana & 1.1 & 3.5 & 1.10 & 1.00 \\
\hline Elphidium crispum & 2.8 & 33.9 & 10.51 & 3.75 \\
\hline SAMPLE MG06 (19.2 m) & & & $1 \%=0.25$ inds & \\
\hline Miliolinella spp. & 1.1 & 4.4 & 1.10 & 1.00 \\
\hline Quinqueloculina arenata & 8.5 & 49.6 & 12.40 & 1.46 \\
\hline Elphidium crispum & 2.5 & 19.5 & 4.88 & 1.95 \\
\hline SAMPLE MG28 (24.5 m) & & & $1 \%=0.39 \mathrm{inds}$ & \\
\hline Quinqueloculina spp. & 1.8 & 28.4 & 11.08 & 6.15 \\
\hline Triloculina trigonula & 4.1 & 10.6 & 4.10 & 1.00 \\
\hline Ammonia beccarii & 0.6 & 8.9 & 3.47 & 5.79 \\
\hline SAMPLE MG29 (43.5 m) & & & $1 \%=0.43 \mathrm{inds}$ & \\
\hline Quinqueloculina & 1.1 & 44.3 & 19.05 & 17.32 \\
\hline Elphidium advenum & 3.0 & 17.8 & 7.65 & 2.55 \\
\hline Nonion victoriensis & 2.3 & 5.3 & 2.30 & 1.00 \\
\hline
\end{tabular}

Table A2.1. Continued 
Foraminiferal biofacies of the Gippsland Shelf, southeastern Australia

\begin{tabular}{|c|c|c|c|c|}
\hline & Live $(\%)$ & Dead $(\%)$ & & Production $(\times)$ \\
\hline SAMPLE MG31 (52.5 m) & & & $1 \%=0.26$ inds & \\
\hline Quinqueloculina spp. & 1.9 & 14.3 & 3.72 & 1.96 \\
\hline Elphidium advenum & 1.9 & 24.8 & 6.45 & 3.39 \\
\hline Elphidium crispum & 0.6 & 4.8 & 1.25 & 2.08 \\
\hline Gaudryina quadrangularis & 0.3 & 4.1 & 1.07 & 3.55 \\
\hline Textularia conica & 0.9 & 3.5 & 0.90 & 1.00 \\
\hline SAMPLE MG35 $(60 \mathrm{~m})$ & & & $1 \%=0.31 \mathrm{inds}$ & \\
\hline Quinqueloculina spp. & 0.8 & 9.3 & 2.88 & 3.60 \\
\hline Textularia sagittula & 1.1 & 3.5 & 1.10 & 1.00 \\
\hline Cibicides mediocris & 1.5 & 18.0 & 5.58 & 3.72 \\
\hline Elphidium advenum & 0.8 & 16.3 & 5.05 & 6.32 \\
\hline SAMPLE MG37 (66.5 m) & & & $1 \%=0.2 \mathrm{inds}$ & \\
\hline Quinqueloculina spp. & 0.4 & 9.8 & 1.96 & 4.90 \\
\hline Cibicides mediocris & 1.6 & 14.3 & 2.86 & 1.79 \\
\hline Discorbis mirus & 0.8 & 4.1 & 0.80 & 1.00 \\
\hline Elphidium advenum & 0.8 & 12.7 & 2.54 & 3.18 \\
\hline Parrellina imperatrix & 1.2 & 10.7 & 2.14 & 1.78 \\
\hline SAMPLE MG38 (78 m) & & & $1 \%=0.12 \mathrm{inds}$ & \\
\hline Cibicides mediocris & 2.3 & 19.8 & 2.30 & 1.00 \\
\hline SAMPLE MG39 (97 m) & & & $1 \%=0.2 \mathrm{inds}$ & \\
\hline Cibicides mediocris & 1.8 & 25.0 & 5.00 & 2.78 \\
\hline Elphidium advenum & 0.7 & 7.9 & 1.58 & 2.26 \\
\hline Uvigerina bassensis & 1.0 & 5.1 & 1.00 & 1.00 \\
\hline SAMPLE MG40 (122 m) & & & $1 \%=0.21 \mathrm{inds}$ & \\
\hline Quinquoculina spp. & 0.7 & 10.9 & 2.29 & 3.27 \\
\hline Cibicides mediocris & 4.5 & 21.0 & 4.50 & 1.00 \\
\hline SAMPLE MG41 (263 m) & & & $1 \%=0.55 \mathrm{inds}$ & \\
\hline Quinquoculina spp. & 1.7 & 3.1 & 1.70 & 1.00 \\
\hline Cibicidoides mediocris & 2.5 & 21.4 & 11.77 & 4.71 \\
\hline Uvigerina bassensis & 1.0 & 5.3 & 2.92 & 2.92 \\
\hline SAMPLE MG42 (170 m) & & & $1 \%=0.23 \mathrm{inds}$ & \\
\hline Cibicides mediocris & 2.1 & 9.1 & 2.10 & 1.00 \\
\hline Uvigerina bassensis & 0.7 & 5.3 & 1.22 & 1.74 \\
\hline
\end{tabular}

Table A2.1. Continued

\section{REFERENCES}

Albani, A. D. 1968. Recent Foraminiferida from Port Hacking, New South Wales. Contributions of the Cushman Foundation for Foraminiferal Research, 19: 85-119.

Albani, A. D. 1978. Recent Foraminifera of an estuarine environment in Broken Bay, New South Wales. Australian Journal of Marine Freshwater Research, 29: 355-398.

Apthorpe, M. 1980. Foraminiferal distribution in the Estuarine Gippsland Lakes System, Victoria. Proceedings of the Royal Society of Victoria, 91: 207-232.

Bard, E., Hamelin, B. \& Fairbanks, R. 1990. U-Th ages obtained by mass spectrometry in corals from Barbados: sea level during the past 130,000 years. Nature, 346: 456-458.

Bartels, G. M. 1979. Geology of Kerrie - Macedon Area / Benthonic foraminifera from Tidal Flats in Western Point Bay. PhD thesis, University of Melbourne.

Boreen, T. D., James, N. P., Wilson, C. \& Heggie, D. 1993. Surficial cool-water carbonate sediments on the Otway continental margin southeastern Australia. Marine Geology, 112: 35-56.

Brenchley, P. J. \& Harper, D. A. T. 1998. Palaeoecology, Ecosystems, Environments and Evolution. Chapman and Hall, London, 1-402.

Cann, J. H. \& De Deckker, P. D. 1981. Fossil Quaternary and living foraminifera from athalassic (non-marine) saline lakes, Southern Australia. Journal of Paleontology, 55: 660-670.

Cann, J. H. \& Gostin, V. A. 1985. Coastal sedimentary facies and foraminiferal biofacies of the St Kilda Formation at Port Gawler, South Australia. Transactions of the Royal Society of South Australia, 109: 121-142.

Cann, J. H., Belperio, A. P., Gostin, V. A. \& Murray-Wallace, C. V. 1988. Sea-Level History, 45,000 to 30,000 yr B.P., Inferred from
Benthic Foraminifera, Gulf St. Vincent, South Australia. Quaternary Research, 29: 153-175.

Cann, J. H., Belperio, A. P., Gostin, V. A. \& Rice, R. L. 1993. Contemporary benthic Foraminifera in Gulf St Vincent, South Australia, and a refined Late Pleistocene sea-level history. Australian Journal Earth Sciences, 40: 197-211.

Carver, R. E. 1971. Procedures in Sedimentary Petrology. John Wiley \& Sons, New York, 1-653.

Chappell, J. \& Shackleton, N. J. 1986. Oxygen isotopes and sea level. Nature, 324: 137-140.

Cochrane, R. M. 1975. Mt Skene and foraminiferid of the Jemmys Point Formation. PhD thesis, University of Melbourne, 1-130.

Collins, A. C. 1953. Pleistocene Foraminifera from Port Fairy, Western Victoria. Memoir of the Natural History of Victoria, 18: 93-105.

Collins, A. C. 1973. Port Phillip survey 1957-1963. Foraminiferida. Memoir of the Natural History of Victoria, 35: 1-62.

Connolly, J. R. 1968. Submarine canyons of the continental margin East Bass Strait (Australia). Marine Geology, 6: 449-461.

Gallagher, S. 1992. Lithostratigraphy, biostratigraphy and palaeoecology of the upper Dinantian platform carbonates in parts of southern and western Ireland. $\mathrm{PhD}$ thesis, National University of Ireland, Volume 1 and 2. 1-503.

Gallagher, S. \& Holdgate, G. R. 1996. Sequence stratigraphy and biostratigraphy of the onshore Gippsland Basin, S.E. Australia. Field Guide Series, 11. Australasian Sedimentologists Group, Geological Society of Australia, 1-70.

Gallagher, S. \& Holdgate, G. R. 2000. The palaeogeographic and palaeo-environmental evolution of a Paleogene mixed siliciclastic cool-water succession in the Otway Basin, southeast Australia. Palaeogeography, Palaeoclimatology, Palaeoecology, 156 (1-2): 19-50. 
Gallagher, S., Jonasson, K. \& Holdgate, G. R. 1999. Foraminiferal biofacies and palaeo-environmental evolution of an Oligo-Miocene cool-water carbonate succession in the Otway Basin, southeast Australia. Journal of Micropalaeontology, 18: 143-168.

Gallagher, S. J., Smith, A. J., Jonasson, K., Wallace, M. W., Holdgate, G. R., Daniels, J. \& Taylor, D. 2001. The Miocene palaeoenvironmental and palaeoceanographic evolution of the Gippsland Basin, Southeast Australia: a record of Southern Ocean change. Palaeogeography, Palaeoclimatology, Palaeoecology, 172: 53-80.

Gibbs, C. F., Tomczak, M. \& Longmore, A. R. 1986. The nutrient regime of Bass Strait Australian Journal of Marine Freshwater Research, 37: 451-466.

Godfrey, J. S., Jones, I. S. F., Garrey, J., Maxwell, H. \& Scott, B. D. 1980. On the Winter Cascade from Bass Strait into the Tasman Sea, Strait. Australian Journal of Marine Freshwater Research, 31: 275286.

Gupta, B. K. \& Marchain-Castillo, M. L. 1993. Benthic foraminifera in oxygen-poor habitats. Marine Micropaleontology, 20: 183-201.

Gupta, A. K. \& Srinivasan, M. S. 1992. Uvigerina proboscidea abundances and paleoceanography of the northern Indian Ocean DSDP Site 214 during the late Neogene. Marine Micropaleontology, 19: $355-367$.

Harris, G., Nilsson, C., Clementson, L. \& Thomas, D. 1987. The Water Masses of the East Coast of Tasmania: Seasonal and Interannual Variability and the Influence on Phytoplankton Biomass and Productivity. Australian Journal of Marine Freshwater Research, 38: 569-590.

Hayward, B. W., Grenfell, H. R., Reid, C. M. \& Hayward, K. A. 1999. Recent New Zealand Shallow-Water Benthic foraminifera: Taxonomy, Ecological Distribution, Biogeography, and use in Paleoenvironmental Assessment. New Zealand Institute of Geological and Nuclear Sciences monograph (Paleontological Bulletin 75), 21: $1-258$.

Hennebert, T. M. \& Lees, A. 1991. Environmental gradients in carbonate sediments and rocks detected by correspondence analysis: examples from the Recent of Norway and the Dinantian of southwest England. Sedimentology, 38: 623-642.

Holdgate, G. R. \& Gallagher, S. 1997. Microfossil Paleoenvironments and Sequence Stratigraphy of Tertiary cool-water carbonates, onshore Gippsland Basin, SE. Australia. In James, N. \& Clarke, J. (Eds), Cool and Temperate Water Carbonates. Special Publication of the Society of Economic Palaeontologists and Mineralogists, 56: 205-220.

James, N. P. 1997. The cool-water carbonate depositional realm. In James, N. \& Clarke, J. (Eds), Cool and Temperate Water Carbonates. Special Publication of the Society of Economic Palaeontologists and Mineralogists, 56: 1-20.

James, N. P., Bone, Y., von der Borch, C. C. \& Gostin, V. A. 1992. Modern carbonate and terrigenous clastic sediments on a cool water, high energy, mid-latitude shelf: Lacepede, southern Australia. Sedimentology, 39: 877-903.

James, N. P., Boreen, T. D., Bone, Y. \& Feary, D. A. 1994. Holocene carbonate sedimentation on the west Eucla Shelf, Great Australian Bight: a shaved shelf. Sedimentary Geology, 90: 161-177.

James, N. P., Collins, L. B., Bone, Y. \& Hallock, P. 1999. Subtropical carbonates in a temperate realm: modern sediments on the southwest Australian shelf. Journal of Sedimentary Research, 69: 1297-1321.

Johnson, K. R. \& Albani, A. D. 1973. Biotopes of Recent benthic Foraminifera in Pitt Water, Broken Bay, New South Wales (Australia). Palaeontology, 14: 265-267.

Jones, H. A. \& Davies, P. J. 1983. Surficial sediments of the Tasmanian continental shelf and part of Bass Strait. Bureau of Mineral Resources Bulletin, Geology and Geophysics, 218: 1-25.

Lees, A. 1989. SedUTIL and AFCal computer packages plus manuals (Version 2.5) 1-23 Université de Louvain, Belgium.
Levitus, S. 1982. Climatological Atlas of the World Ocean. NOAA Professional Paper, 13: 1-173.

Li, Q. \& McGowran, B. 1997. Miocene climatic oscillation recorded in the Lakes Entrance oil shaft, southern Australia; benthic foraminiferal response on a mid-latitude margin. Micropaleontology, 43: 149-164

Li, Q., McGowran, B., James, N. P. \& Bone, Y. 1996a. Foraminiferal biofacies on the mid-latitude Lincoln Shelf, South Australia: oceanography and sedimentological implications. Marine Geology, 129: 285-312.

Li, Q., McGowran, B., James, N. P., Bone, Y. \& Cann, J. H. 1996b. Mixed Foraminiferal Biofacies on the Mesotrophic, MidLatitude Lacepede Shelf, South Australia. Palaios, 11: 176-191.

Li, Q., Quilty, P. G., Moss, G. \& McGowran, B. 1996c. Southern Australian endemic and semi-endemic Foraminifera; a preliminary report. Journal of Micropalaeontology, 15: 169-185.

Li, Q., James, N. P., Bone, Y. \& McGowran, B. 1999. Palaeoceanographic significance of recent foraminiferal biofacies on the southern shelf of Western Australia: a preliminary study. Palaeogeography, Palaeoclimatology, Palaeoecology, 147: 101-120.

Li, L., Gallagher, S. J. \& Finlayson, B. 2000. Foraminiferal response to Holocene environmental changes of a tidal estuary in Victoria, Southeastern Australia. Marine Micropaleontology, 38: 229-246.

Martinez, J. I. L. 1994. Late Pleistocene palaeoceanography of the Tasman Sea: Implications for the dynamics of the warm pool in the western Pacific. Palaeogeography, Palaeoclimatology, Palaeoecology, 112: $19-62$.

Melguen, M. 1974. Facies analysis by "correspondence analysis" numerous advantages of this new statistical technique. Marine Geology, 17: 165-182.

Murray, J. W. 1973. Distribution and Ecology of Living Benthic Foraminifera. Heineman, London, 1-274.

Murray, J. W. 1991. Ecology and Palaeoecology of Benthic Foraminifera. Longman Scientific and Technical, Harlow, 1-397.

Parr, W. J. 1945. Recent Foraminifera from Barwon Heads, Victoria. Proceedings of the Royal Society of Victoria, 56: 189-199.

Parr, W. J. 1941. A new genus, Planulinoides, and some species of Foraminifera from Southern Australia. Mining and Geological Journal, 2: 305

Pickard, N. A. H. 1994. Sedimentology of the upper Dinantian Charlestown Main Limestone: implications for the controls on cyclotherm deposition, eastern Midland Valley of Scotland. Scottish Journal of Geology, 30 (1): 15-31.

Quilty, P. G. 1974. Tasmanian Tertiary foraminifer; Part 1. Papers and Proceedings of the Royal Society of Tasmania, 108: 31-106.

Quilty, P. G. 1982. Tasmanian Tertiary Foraminiferida; Part 3. Discorbacea (Eponididae) to Nonionacea. Papers and Proceedings of the Royal Society of Tasmania, 116: 5-52.

Taylor, D. J. \& Mee, V. M. 1970. The Gippsland Marine Sequence from a Micropalaeontological and Paleobiological Viewpoint. Unpublished Palaeontological Report, Esso Australia Ltd, Melbourne.

Taylor, D. J., Mee, V. M. \& Clamp, J. A. 1972. An analysis of Benthic foraminiferal faunas of the Gippsland Basin. Unpublished Palaeontological Report, Esso Australia Ltd, Melbourne.

Thomas, E. \& Gooday, A. J. 1996. Cenozoic deep-sea benthic foraminifers: Tracers for changes in oceanic productivity?. Geology, 24: 355-358.

Tomczak, M. 1985. The Bass Strait Water Cascade during winter 1981. Australian Journal of Marine Freshwater Research, 32: 699-708.

Walton, W. R. 1952. Techniques for Recognition of Living Foraminifera. Contributions of the Cushman Foundation for Foraminiferal Research, 3: 56-60.

Yassini, I. \& Jones, B. G. 1995. Foraminiferida and ostracoda from estuarine and shelf environments on the southeastern coast of Australia. The University of Wollongong Press, Wollongong, 1-484. 